\title{
Green Practice by Utilization of Waste Water Blowdown as Domestic Water PT. PJB UP Muara Tawar
}

\author{
Trio Suryono ${ }^{1}$, Riski Aditya ${ }^{1}$, Kevin Sanjoyo Gunawan ${ }^{2}$, Totok R. Biyanto ${ }^{2 *}$ \\ ${ }^{I}$ PT. PJB UP Muara Tawar, Muara Tawar, Indonesia \\ ${ }^{2}$ Engineering Physics Department, Institut Teknologi Sepuluh Nopember (ITS), Surabaya, Indonesia.
}

\begin{abstract}
In PT. PJB UP Muara Tawar, amount of domestic water consumption is higher than ammount of available water from groundwater and district Water Company. In order to fulfill of domestic water demand, improvement to increase water availability in PT. PJB UP Muara Tawar is needed. One of solution is reuse wastewater from continuous blowdown (CBD). CBD wastewater is the contaminated water especially solid content along steam water cycle. CBD waste processing has been done to process waste water into domestic water. From laboratory test results were obtained the best mixture of waste and fresh water with a ratio of 1:48 to produce domestic water. From an economical view of point, this process can reduce costs for the production or purchase of raw water. During 6 months, the obtained saving is IDR 62.822.259, -
\end{abstract}

Keywords: $C B D$, cycle, reuse, water, waste

\section{Introduction}

Water in electric generation is an essential material [1]. Operation of combined cycle power plant (CCPP) requires some of water to producing steam with certain quality and quantity [2]. The water as the main raw material is heated in the Heat Recovery Steam Generation (HRSG) on CCPP to produce superheated steam [3]. This superheated steam is the main driver of steam turbine. It will be recycled. In water steam recycle, there are some losses that required make up water. Make up water in steam turbine is produced through several steps in BOP (Balance of Plant). Utilization of water in PT. PJB UP Muara Tawar is used for electricity generation and domestic water to supply building water consumption in the area of PT.PJB UP Muara Tawar. Domestic water used in administrative buildings, guesthouses, canteens, mosque, LK3 building, B building, and P2B building, etc. with average water usage $42.66 \mathrm{~m} 3 /$ day. The use of amount domestic water is proportional to the activities in the whole areas [4]. Amount of domestic water consumption is higher than amount of available water from groundwater and district water company i.e. $32.88 \mathrm{~m} 3 /$ day.

In order to fulfill of domestic water demand, improvement to increase water availability in PT. PJB UP Muara Tawar is needed. One of solution is reuse wastewater from continuous blow down (CBD). CBD wastewater is the contaminated water especially solid content along steam water cycle.

In CCPP Muara Tawar, CBD is blow down from Low Pressure (LP) Drum, with normal valve opening of $15 \%$. In this paper, utilization of waste water from CBD for domestic water consumption in PT. PJB UP Muara Tawar and district water will be described.

\subsection{CBD System}

II. Theory

Boiler blowdown is water intentionally wasted from a boiler to avoid concentration of impurities during continuing evaporation of steam. The water is blown out of the boiler with some force by steam pressure within the boiler. Bottom blowdown used with early boilers caused abrupt downward adjustment of boiler water level and was customarily expelled downward to avoid the safety hazard of showering hot water on nearby individuals

In PT. PJB UP Muara Tawar, CBD is layed on LP drum, with open the valve continuously with a normal valve opening of $15 \%$. Continuous opening of CBD is intended to: decrease mineral content that will cause deposition, erosion, and corrosion problems in all piping and equipments. $\mathrm{Na}_{3} \mathrm{PO}_{4}$ (Phosphate) is used to maintain quality of water. In steam turbine there are $3 \mathrm{Na}_{3} \mathrm{PO}_{4}$ pumps for each $\mathrm{HP}$ drum and $3 \mathrm{Na}_{3} \mathrm{PO}_{4}$ pumps for each LP drum. The main $\mathrm{Na}_{3} \mathrm{PO}_{4}$ pumps that continous injected to the system are injected in HP drum. Meanwhile the secondary $\mathrm{Na}_{3} \mathrm{PO}_{4}$ pumps that injected in $\mathrm{LP}$ drum is regulated to maintain $\mathrm{pH}$ setpoint. The schematic diagram of the LP drum is shown in Fig. 1. 


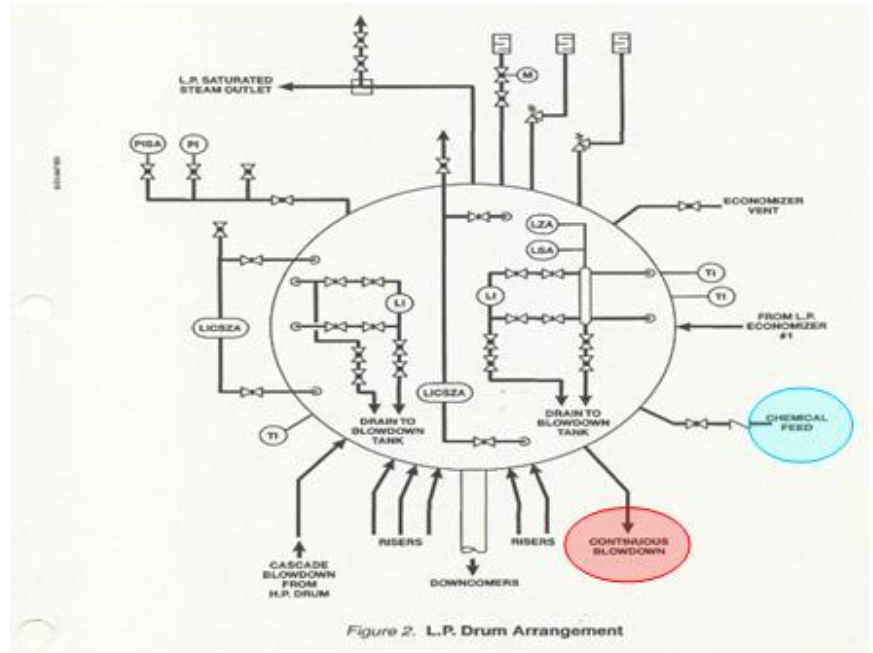

Figure 1. Line LP Drum

III. Method

The water quality control is performed offline by sampling the water contain in laboratory. Water sampling continues blow down at blowdown tank is shown in Fig. 2.

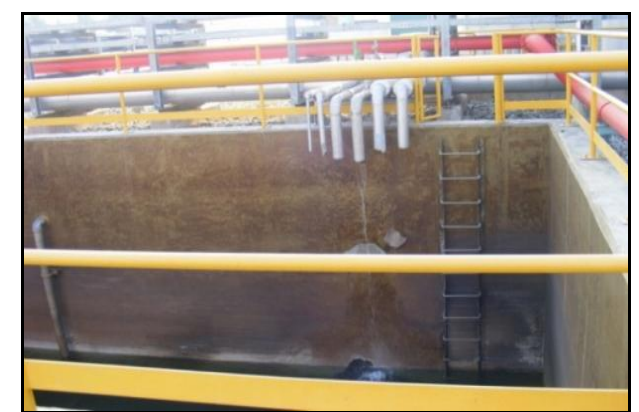

Figure2. Water Sampling at CBD Water Tank

In order to recycle CBD wastewater, some tank should be added and piping modification are required. The CBD water recycle system for HRSG 1.1, HRSG 1.2, HRSG 1.3 are shown in Fig. 3.

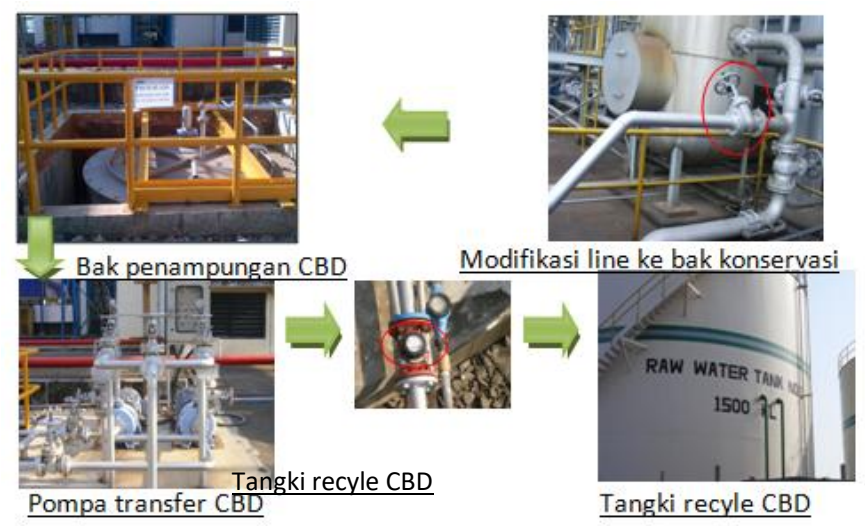

Figure 3. Modification of CBD Water Recycle.

Fig. 4 shows CBD system before the addition of a storage tank, meanwhile Fig. 5 shows CBD system after the addition of a storage tank. From these figures some modification is required especially in storage tank. The layout of storage tank in the plant is shown in Fig. 6. The storage tank was designed according to mass balance of blowdown water, and the design result is shown in Fig. 7. 


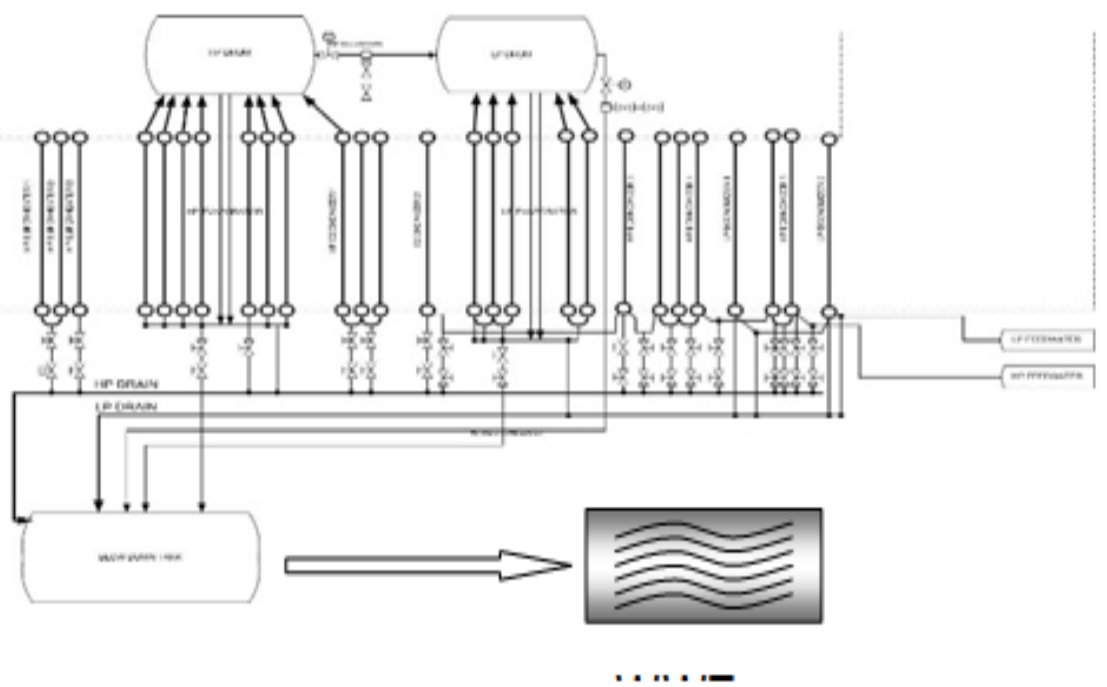

Figure 4. Continous Blow Down Before Modification

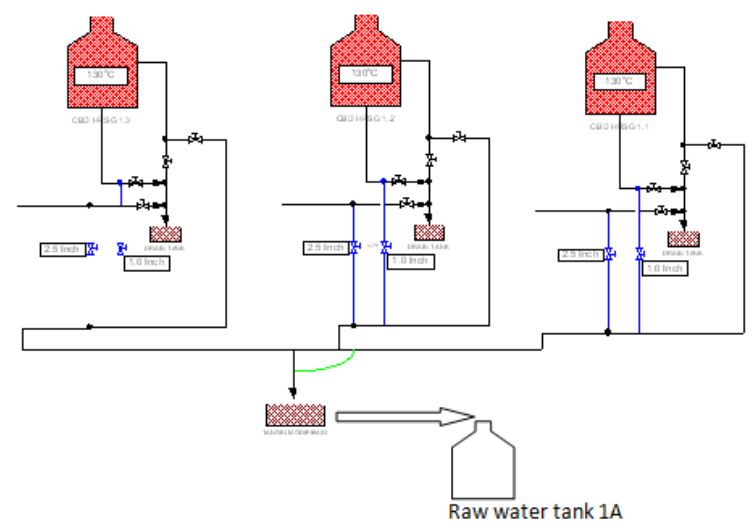

Figure 5. CBD After Modification

Utilization and design of raw water tank shown in Fig. 6 and Fig. 7.

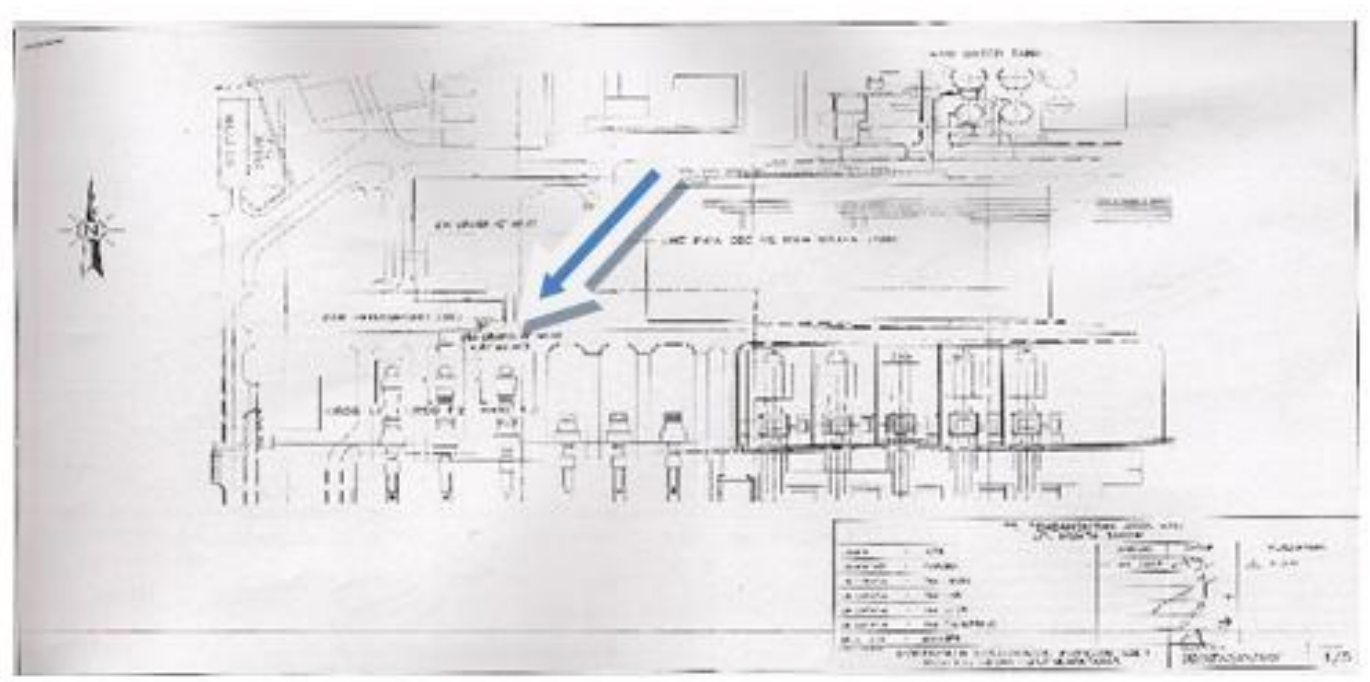

Figure 6. Layout Plant of CBD Tank 


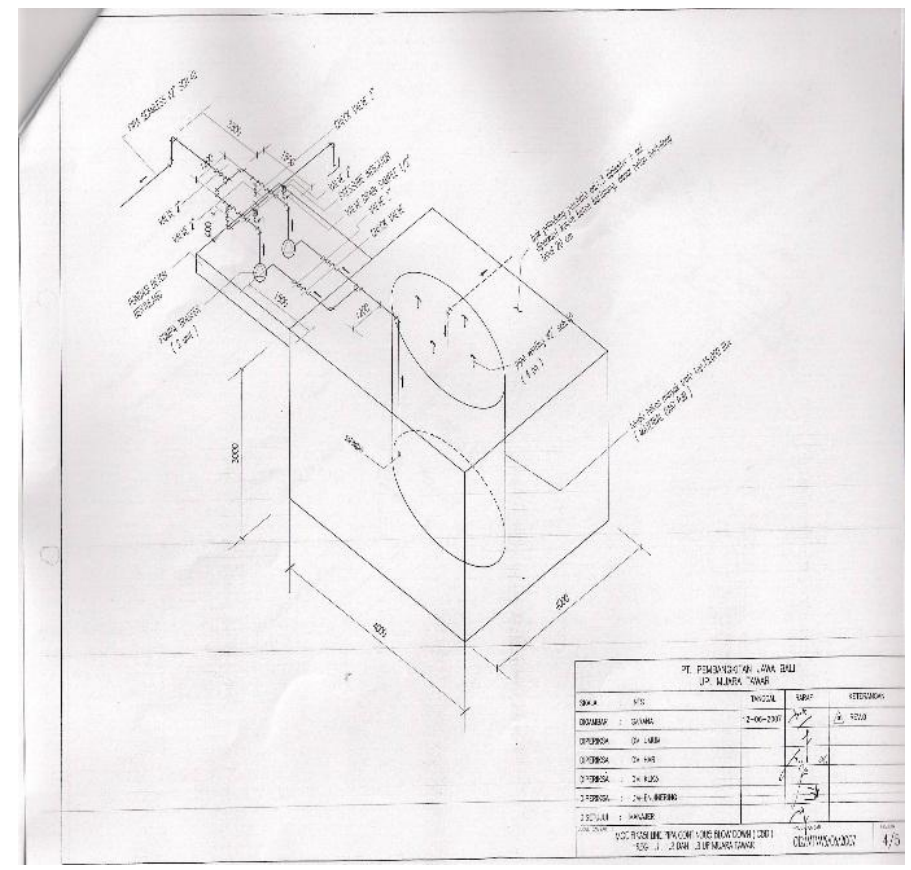

Figure 7. Designed Tank

The detail of investment regarding the storage tank and piping system can be described as follows:
- Materials
: IDR 356.295.519, -
- Costs and fees
: IDR 114.252.050, -
: IDR 470.547.569, -

Feasibility study, engineering design and construction were started on mid-October 2007, and it is completed on 7 April 2008.

\subsection{Wastewater Quality}

\section{Results And Driscussions}

The properties of CBD water that was taken on 20 August 2005 as shown in Table 1 . The conductivity of water was exceed the limit. In order to match with domestical water requirements, mixing with fresh water is required.

Table 1. CBD Waste Water Quality

\begin{tabular}{|c|c|c|c|c|c|c|}
\hline No & Sample & $\begin{array}{c}\text { Temperature } \\
\left({ }^{0} \mathbf{C}\right)\end{array}$ & $\begin{array}{c}\text { Conductivity } \\
(\boldsymbol{\mu S} / \mathbf{C m})\end{array}$ & $\begin{array}{c}\text { SiO2 } \\
(\mathbf{p p m})\end{array}$ & $\begin{array}{c}\mathbf{C l}- \\
(\mathbf{p p m})\end{array}$ & $\mathbf{p H}$ \\
\hline 1 & HRSG 1.1 & 88,9 & 26,2 & 0,23 & 0,18 & 7,85 \\
\hline 2 & HRSG 1.2 & 95 & 35,4 & 0,28 & 0,34 & 7,97 \\
\hline 3 & HRSG 1.3 & 91,3 & 33,8 & 0,34 & 0,37 & 8,01 \\
\hline 4 & Raw Water 1A & 35 & 7,62 & 0,047 & 0,08 & 7,40 \\
\hline 5 & Raw Water 1B & 36 & 7,89 & 0,071 & 0,15 & 7,26 \\
\hline & & $<20$ & $<2$ & $<1.0$ & $6-8$ \\
\hline
\end{tabular}

Table 2. is the tabulated properties of fresh water as mixing water to CBD water. This effort will reduce the conductivity of CBD water as raw material of domestic water.

Table 2. Distillate Desal 2 Quality

\begin{tabular}{|l|l|l|l|l|}
\hline No. & Item & Distillate Desal 2 & Limit & Status \\
\hline \hline 1 & Conductivity $(\mu \mathrm{S} / \mathrm{Cm})$ & 7,51 & $<20$ & Match \\
\hline 2 & $\mathrm{pH}$ & 6,98 & $7 \sim 8$ & Match \\
\hline 3 & Silica $(\mathrm{ppm})$ & ND & $<2$ & Match \\
\hline
\end{tabular}

To assure the quality of mixing water, laboratory work should be done before implementation, as shown in Fig. 8. From experiment in laboratory, the raw water properties can be achieved with the ratio of CBD and fresh water is 1:48. The laboratory test results of mixed water from the plant show the properties of mixing water were match with domestic water properties as shown in Table 3. 


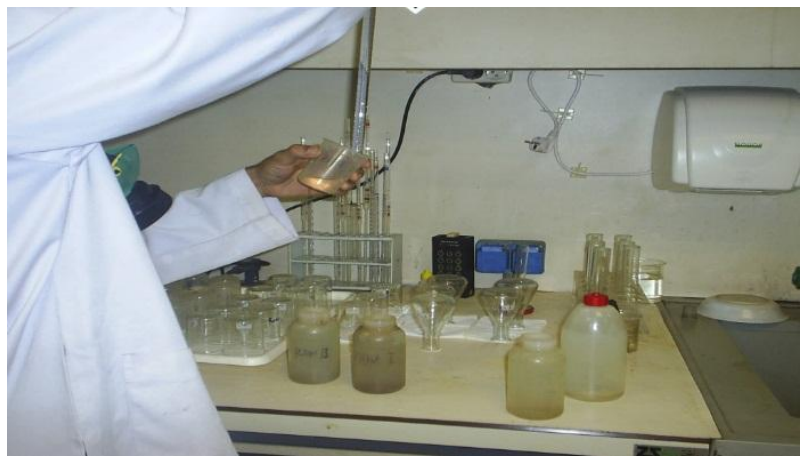

Figure 8. Mixing CBD HRSG 1.1 and Distillate Desal 2

Table 3. Experiment Result

\begin{tabular}{|l|l|l|l|}
\hline No. & Item & Distillate Desal 2 + HRSG 1.1 Waste & Limit \\
\hline \hline 1 & Conductivity $(\mu \mathrm{S} / \mathrm{Cm})$ & 7,50 & $<20$ \\
\hline 2 & $\mathrm{pH}$ & 7,01 & $6 \sim 8$ \\
\hline 3 & Silica $(\mathrm{ppm})$ & ND & $<0,2$ \\
\hline
\end{tabular}

\subsection{Economic Analysis}

Water are very important in ST 1.4 operations. Recycle and reuse of CBD waste into Raw Water Tank 1A obtain financial benefits as follows:

Table 4. Profit and Production Report

\begin{tabular}{|c|c|c|c|c|c|}
\hline No & Month & $\begin{array}{l}\text { Counter } \\
\text { (m3/month) }\end{array}$ & $\begin{array}{l}\text { Raw Water Cost } \\
\text { (IDR/m3) }\end{array}$ & $\begin{array}{l}\text { Profit } \\
\text { (IDR/month) }\end{array}$ & $\begin{array}{l}\text { Cumulative } \\
\text { Profit }\end{array}$ \\
\hline 1 & April & 2,161 & 100,423 & $217,014,103$ & $217,014,103$ \\
\hline 2 & May & 2,590 & 100,423 & $260,095,570$ & $477,109,673$ \\
\hline 3 & June & 1,471 & 100,423 & $147,722,233$ & $624,831,906$ \\
\hline 4 & July & 1,836 & 100,423 & $184,376,628$ & $809,208,534$ \\
\hline 5 & August & 2,074 & 100,423 & $208,277,302$ & $1,017,485,836$ \\
\hline 6 & September & - & 100,423 & - & - \\
\hline 7 & October & - & 100,423 & - & - \\
\hline$\varepsilon$ & November & - & 100,423 & & - \\
\hline c & December & - & 100,423 & - & - \\
\hline & Total & 10,132 & & 1017485836 & - \\
\hline & Average & $2,026.4$ & & 203497167 & - \\
\hline No & & $\begin{array}{l}\begin{array}{l}\text { Counter } \\
\text { (m3/month) }\end{array} \\
\end{array}$ & $\begin{array}{l}\text { Raw Water Cost } \\
\text { (IDR/m3) }\end{array}$ & $\begin{array}{l}\text { Profit } \\
\text { (IDR/month) }\end{array}$ & $\begin{array}{l}\text { Cumulative } \\
\text { Profit }\end{array}$ \\
\hline 1 & April & 1,169 & 100,423 & $117,394,487$ & $1,134,880,323$ \\
\hline $\begin{array}{l}\text { Total 2008- } \\
2009\end{array}$ & & 11,301 & 0 & $113,4880,323$ & - \\
\hline Average & & $1,883.5$ & 0 & $189,146,721$ & - \\
\hline
\end{tabular}

To operate the mixing plant, it required operating cost for pumping process as follow:

$30 \mathrm{KW}$ x 12 hours x 30 days x 6 months x IDR 1800 / KWh

$=$ IDR 116,640,000, -

Meanwhile, as shwon in Table 4. the revenue of $11.301 \mathrm{~m}^{3}$ water is IDR. 1.134 .880 .323 . Therefore the profit is: IDR. 1.134.880.323 - IDR. 116.640.000 = IDR. 1.018.240.323

The utilization of CBD water also can be used for process itself. The reduction cost of purchased raw water for steam generation is IDR. 62.822.259 during six months

\section{Conclusion}

CBD waste processing has been done to process waste water into domestic water. From laboratory test results were obtained the best mixture of waste and fresh water with a ratio of 1:48 to produce domestic water. From an economical view of point, this process can reduce costs for the production or purchase of raw water. During 6 months, the obtained saving is IDR 62.822.259, -.

\section{Acknowledgement}

The authors gratefully thank to PT. PJB UP Muara Tawar - Indonesia for providing the facilities in conducting this research. 


\section{References}

[1]. G. Olson, Water and Energy: threats and opportunities, London: IWA Publisher, 2012

[2]. B. Ali and A. Kumar, "Development of life cycle water footprints for gas-fired power generation technology," Energy Conversion Management, vol. 110, no. 15, pp. 386-396, 2016.

[3]. J. Li, K. Wang and L. Cheng, "Experiment and optimization of a new kind once-through heat recovery steam generator (HRSG) based on analysis of exergy and economy," Applied Thermal Engineering, vol. 120, pp. 402-415, 2017.

[4]. E. Domene and D. Sauri, "Urbanisation and water consumption: influencing factors in the metropolitan region of Barcelona," Urban Study, vol. 43, no. 9, pp. 1605-1623, 2006

[5]. J. Kang, K. Grable, G. Hustvedt and M. Ahn, " Sustainable water consumption: The perspective of Hispanic consumers," Journal of Environmental Psychology, vol. 50, pp. 94-103, 2017.

[6]. F. D. Survis and T. L. Root, " The rain-watered lawn: Informing effective lawn watering behavior," Journal of Environmental Management, vol. 199, pp. 109-115, 2017.

[7]. A. Maas, C. Goemans, D. Manning and S. Kroll, " Evaluating the effect of conservation motivations on residential water demand," Journal of Environmental Management, vol. 196, pp. 394-401, 2017. 